\title{
CARNIVORE IMPACT ON CAVE BEAR BONES AND THE ANALYSIS OF THEIR DISPERSION. CASE STUDY: URŞILOR CAVE (NW ROMANIA)
}

\author{
VPLIV ZVERI NA KOSTI JAMSKIH MEDVEDOV IZ \\ JAME URŞILOR (SZ ROMUNIJA) IN ANALIZA NJIHOVE \\ RAZKROPLJENOSTI
}

\author{
Marius ROBU ${ }^{*}$, Alexandru PETCULESCU ${ }^{2}$, Ionuț-Cornel MIREA ${ }^{3}$, Marius KENESZ ${ }^{4}$, Marius VLAICU ${ }^{5}$ \\ \& Silviu CONSTANTIN ${ }^{6}$
}

\begin{abstract}
UDC 56:599.744.21(498)

Marius Robu, Alexandru Petculescu, Ionuț-Cornel Mirea, Marius Kenesz, Marius Vlaicu \& Silviu Constantin: Carnivore impact on cave bear bones and the analysis of their dispersion. Case study: UrŞilor cave (NW Romania)

In taphonomy, the study of carnivore modification of fossil bones and the analysis of their dispersion represent the best approach to assessing the extent of bone modification and displacement for a given bone assemblage. Here we analyze the excavated bone deposit from Urşilor Cave, a well-documented and fossil-rich Upper Pleistocene cave bear site from the Romanian Carpathian Mountains. More than 1400 limb bones or bone remains were analyzed $\left(\mathrm{NISP}_{\text {left and right }}=1424\right)$ and 69 measurable puncture marks were identified, measured and morphologically analyzed. Moreover, for assessing the degree of bone scattering, almost 540 cave bear limb bones and mandibles were refitted and the Index of Skeletal Disjunction (ISD) was calculated for the entire bone assemblage. More than $30 \%$ of the analyzed cave bear limb bones were affected by carnivores: the ulnae were the most affected $(39.3 \%)$ while the humeri and femora were less modified $(24.7 \%$ and $25.5 \%$, respectively). The range of variation in size of the puncture marks, the morphological features of various tooth marks and the faunal composition of the studied bone assemblage indicate that at least two carnivore taxa are responsible for the bone modifica-
\end{abstract}

\begin{abstract}
Izvleček
UDK 56:599.744.21(498)

Marius Robu, Alexandru Petculescu, Ionuț-Cornel Mirea, Marius Kenesz, Marius Vlaicu \& Silviu Constantin: Vpliv zveri na kosti jamskih medvedov iz jame UrŞilor (SZ Romunija) in analiza njihove razkropljenosti

Proučevanje sledov zveri na fosilnih kosteh in razkropljenosti kosti $\mathrm{v}$ prostoru je najboljše tafonomsko orodje za pridobivanje podatkov o obsegu takšnih pojavov znotraj posameznega paleontološkega zbira. $\mathrm{V}$ raziskavi obravnavamo kosti jamskega medveda iz jame Urşilor, dobro raziskanega mlajšepleistocenskega najdišča v Romunskih Karpatih. Analizirali smo več kot 1424 dolgih cevastih kosti okončin ali njihovih odlomkov in pri tem prepoznali, izmerili in morfološko analizirali 69 odtiskov zob. Poleg tega smo izračunali indeks razkropljenosti okostja (Index of Skeletal Disjunction, ISD) za celotni paleontološki zbir, zaradi česar smo sestavili skoraj 540 dolgih cevastih kosti okončin in spodnjih čeljustnic jamskega medveda. Sledove zveri smo prepoznali na več kot $30 \%$ kosti okončin, najpogosteje na komolčnicah (39.3\%), nekoliko redkeje pa na nadlahtnicah in stegnenicah $(24.7 \%$ oz. $25.5 \%)$. Variabilnost $\mathrm{v}$ velikosti odtiskov zob, njihovih morfoloških značilnostih in favnistični sestavi proučevanega paleontološkega zbira pričajo o tem, da sta ugotovljene spremembe medvedjih kosti povzročili vsaj dve različni zveri. Vrednosti indeksa razkropljenosti okostja kažejo na izrazitejšo razkropljenost stegnenic v primerjavi
\end{abstract}

\footnotetext{
${ }^{1}$ Marius Robu, “Emil Racoviță” Institute of Speleology, Romanian Academy, Calea 13 Septembrie 13, 050711 Bucharest, Romania, e-mail: marius.robu@iser.ro

${ }^{2}$ Alexandru Petculescu, "Emil Racoviță” Institute of Speleology, Center for Geochronology and Paleoclimate, str. Frumoasă 31, 010986 Bucharest, Romania, e-mail: alexpet@gmail.com

${ }^{3}$ Ionuț-Cornel Mirea, "Emil Racoviță” Institute of Speleology, Center for Geochronology and Paleoclimate, str. Frumoasă 31, 010986 Bucharest, Romania, e-mail: ionut.mirea@iser.ro

${ }_{4}^{4}$ Marius Kenesz, "Emil Racoviță" Institute of Speleology, Cluj-Napoca Branch, Clinicilor 5, 400006 Cluj-Napoca, Romania, e-mail: marius_kenesz@yahoo.com

${ }^{5}$ Marius Vlaicu, "Emil Racoviță” Institute of Speleology, Romanian Academy, Calea 13 Septembrie 13, 050711 Bucharest, Romania, e-mail: mariusv_iser@yahoo.com

${ }^{6}$ Silviu Constantin, "Emil Racoviță” Institute of Speleology, Center for Geochronology and Paleoclimate, str. Frumoasă 31, 010986 Bucharest, Romania, e-mail: silviu.constantin@iser.ro

*Corresponding Author
}

Received/Prejeto: 26.11.2015 
tions. The results obtained for the ISD index indicate higher displacement for femora when compared to other bones (e.g. tibiae, mandibles, humeri). Our analyses of bone modifications caused by carnivores indicate a low level of the scattering of intensely modified (by in situ consumption) bones, and notable carnivore impact on the configuration of the bone assemblage. Key words: Ursus spelaeus, taphonomy, ISD, tooth marks, Urşilor Cave, Romanian Carpathians. z drugimi kostmi (npr. golenicami, nadlahtnicami, spodnjimi čeljustnicami). Naša analiza kaže na skromno razkropljenost intenzivno obgrizenih kosti (zaradi hranjenja v sami jami) in znaten vpliv zveri na konfiguracijo paleontološkega zbira.

Ključne besede: Ursus spelaeus, tafonomija, ISD, ugrizi, jama Urşilor, Romunski Karpati.

\section{INTRODUCTION}

The study of carnivore impact on bones from a cave bear thanatocoenosis allows researchers to: (i) detect a taxon/ species presence in the absence of osteological remains of that species, (ii) determine carnivore patterns of carcass consumption, and (iii) collect valuable data for palaeofaunistic reconstruction. Using a taphonomic approach many European cave bear (Ursus spelaeus) sites have been intensively investigated and the carnivore impact on $U$. spelaeus remains has been assessed over the past few decades (e.g., Tintori \& Zanalda 1992; Stiner et al. 1996; Pacher 2000, 2004; Bona 2003; Quilès 2003; DomínguezRodrigo \& Piqueras 2003; Döppes 2004; Fosse et al. 2004; Pinto-Llona \& Andrews 2004; Martínez-Sánchez et al. 2012; Arilla et al. 2014; Fourvel et al. 2014). Although the Romanian Carpathians have great potential for addressing these issues, relevant publications are lacking, except for Jurcsák et al. (1981), Quilès et al. (2006) and Pacher \& Quilès (2013).

The aim of this study was to analyze the carnivore impact on cave bear limb bones found within the palaeontological excavation at Urşilor Cave, Romania. We specifically address the following research questions: 1) What is the magnitude of the carnivore activity? 2) Which types of tooth marks are found on the limb bones? 3) What taxa were likely to have been responsible for bone modification?

Apart from the cave bears, several carnivore fossil species were listed from Urşilor Cave, for both the upper and lower levels (Jurcsák et al. 1981; Terzea 1978, 1989; Constantin et al. 2014; Robu 2015): cave lion (Panthera spelaea), brown bear (Ursus arctos), spotted hyena (Crocuta crocuta spelaea), wolf (Canis lupus), and fox (Vulpes vulpes). Moreover, a fully articulated cave lion and a nearly complete skeleton of a hyena were also recovered from the Scientific Reserve located only 12 meters south of the palaeontological excavation site.

Lyman (2004) showed that analysis of the horizontal and vertical provenance of refitting or conjoining pieces (i.e., scattering analysis) can be a valuable analytical tool for understanding site formation processes. The scattering analysis may be performed via anatomical refitting, which uses the principle of bilateral symmetry of paired bones (Todd 1987). As it is suitable for the excavated bone assemblage from Urşilor Cave, such investigation may provide clues to the assemblage genesis (either deposition in situ or reworking). This is the first scattering analysis undertaken in a cave.

\section{GEOLOGICAL AND GEOGRAPHICAL SETTING}

Urşilor Cave is situated in the Northwestern part of the Romanian Carpathians, at 491 m a.s.l., in Bihor Mountains (Fig. 1). The studied material was collected from the palaeontological excavation situated at the lower level of the cave, in the Scientific Reserve (Excavation Chamber). The geological, geomorphological and sedimentological background of the site have previously been assessed and discussed in detail (Constantin et al. 2014; Robu 2015). 




Fig. 1: Urşilor Cave map.

\section{MATERIALS AND METHODS}

\section{CARNIVORE IMPACT ON CAVE BEAR LIMB BONES}

In order to assess the impact of carnivores on the cave bear bones, more than 1400 limb bones or bone remains were analyzed (Number of Identified Specimens: $\left.\mathrm{NISP}_{\text {left and right }}=1424\right)$ and the number of specimens with traces of carnivore activity was quantified. Juvenile and adult bones were pooled together for the analysis.

Carnivore damage on the fossil remains was studied on the long limb bones (LLB: humeri, ulnae, radii, femora and tibiae) from the left and right sides of the body. The carnivore impact features were classified into three categories, destruction, gnaw, and puncture marks:

Destruction marks [bone splinters and flakes (sensu Lyman 2004)] - they suggest heavy bone destruction/ crushing, related to durophagous carnivores (e.g., hyenas, wolves) (Fig. 2A).

Gnaw marks [ragged-edged chewing/crenulated edges and striations/gouge marks/scoring/tooth scratches/furrows (Maguire et al. 1980; Binford 1981; Shipman 1981; Haynes 1980, 1983; Lyman 2004; Campmas \& Beauval 2008; Domíninguez-Rodrigo et al. 2012; Fourvel et al. 2012, 2014)] - damage either on the edges or on the diaphysis of a bone. These features, when affecting the diaphysis, have the appearance of elongate grooves that may vary in cross-section, from "V" - to "U"-shaped (Shipman 1981); when affecting the bone edges of diaphysis, they have an almost saw-like shape (Fig. 2B).

Puncture marks [shallow pitting/punctures depressions/perforations/pits (Maguire et al. 1980; Binford
1981)] - are the result of the pressure of teeth leaving a clear depression; often with flakes on the outer wall of

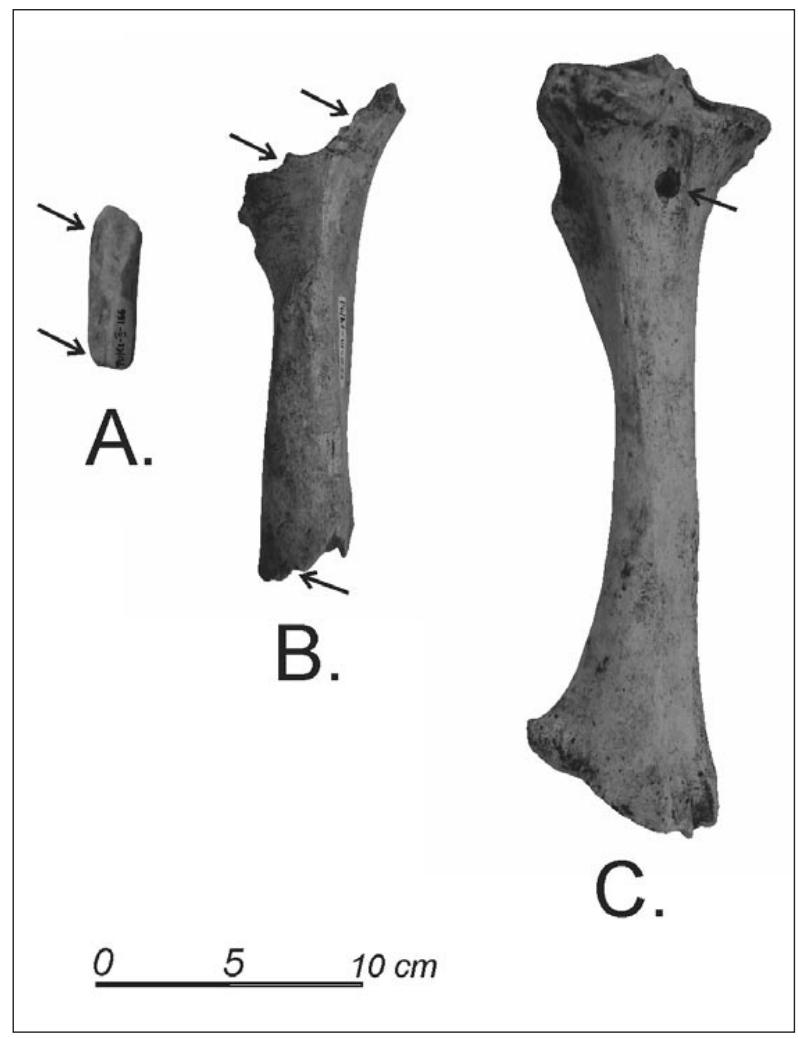

Fig. 2: Carnivore impact on cave bear bones. A - destruction marks; $B$ - gnaw marks; $C$ - puncture marks. 
the bone (Maguire et al. 1980; Fosse et al. 2004; Lolliot \& Philippe 2004; Fourvel et al. 2012, 2014) (Fig. 2C).

The occurrences of the above mentioned features on the analyzed bones (both the left and right limbs) were counted, and their position (on the proximal and/or distal epiphyses, and/or the diaphysis) was assessed. Width (DT: transversal diameter) and length (DAP: anteroposterior diameter) of 69 measurable puncture marks (in $\mathrm{mm}$ ) were measured with an electronic caliper (standard error $>0.01 \mathrm{~mm}$ ) and plotted on a bivariate graph in order to identify the taxon responsible for the bone modifications. Previous work by Domínguez-Rodrigo and Piqueras (2003) demonstrated that puncture marks made on the same bone may differ in size depending on the typology of the bone tissue in question (i.e., cancellous vs. cortical bone); thus, we measured and analyzed marks made on different bone tissues separately. These data were compared to previous results obtained in the Pyrenees Mountains, focused on modern brown bears (Arilla et al. 2014) and fossil and modern hyenas from Africa and Europe, respectively (Fourvel 2012).

\section{SCATTERING ANALYSIS (ISD - INDEX OF SKELETAL DISJUNCTION)}

In order to assess the degree of scattering of a bone assemblage, Todd (1987) proposed a method for paired bones which can be anatomically refitted, the so-called Index of Skeletal Disjunction (ISD). This index was individually calculated for each paired skeletal element (for different cave bear limb bones and mandibles) in several steps: first, the minimum distance (MD; linear distance) between each anatomically refit pair was measured. The second step was the calculation of the average minimum distance for each kind of paired skeletal element $\left(\mathrm{MD}_{\mathrm{i}}\right)$. The third step consisted of multiplying the number of conjoined pairs by two, and adding the number of unpaired bone specimens in the collection to produce the total number of bones in each category (= skeletal element). Fourth, the number of conjoined bones was divided by the total number of bones in a category to derive the percentage of bones with mates. The mean minimum distance between anatomically refit specimens (in meters) was then divided by the percentage of bones with mates and multiplied by 100 (equation [1] below). The resulting numbers were scaled from 1 to 100 to derive the ISD (sensu Lyman 2004). The equation applied was:

ISD $=\frac{\text { MDi } / \% \text { of } i \text { that anatomically refit } \times 100}{\text { maximum value in the numerator for the assemblage }}$

Almost 540 cave bear limb bones and mandibles were analyzed in our study. High-resolution photographs and excavation maps were used for each quadrant and level, in order to measure the minimum distance between each anatomically refit pair. The refitting procedure was applied according to the method defined by Todd (1987). Moreover, the paired bones were vectorised, scaled and graphically represented. The standardized ISD values indicate the degree of bone scattering - the lower the ISD value, less scattered is the skeletal specimen.

\section{RESULTS AND DISCUSSION}

\section{CARNIVORE IMPACT ON CAVE BEAR LIMB BONES}

The most numerous skeletal elements recovered from the palaeontological excavation site were femora NISP $_{\text {femora }}$ $=337)$ and humeri $\left(\right.$ NISP $\left._{\text {humeri }}=333\right)$, while the lowest values were recorded for ulnae $\left(\right.$ NISP $\left._{\text {ulnae }}=244\right)$. The NISP values obtained for both the radii and tibiae were identical $\left(\mathrm{NISP}_{\text {radii/tibiae }}=255\right)$.

Slightly over $30 \%$ of the recovered bones were affected by carnivores (Tab. 1). There was no noticeable difference in carnivore modification between the bones from the left and right side. Nonetheless, the left side humeri, ulnae and tibiae, as well as the right side radii and femora presented slightly more tooth marks.

Figs. 3 and 4 show the carnivore modifications documented for the cave bear forelimb and hindlimb bones. After calculating the total number of modified bones (the left and right-side occurrences of the tooth marks) relative to the NISP (for each limb bone), ulnae were the most affected by carnivore activity $(39.3 \%$; mainly the diaphysis and the olecranon process). The radii and tibiae were equally damaged (33.4\%), while the humeri and femora were less affected by carnivore activity (24.7\% and $25.5 \%$, respectively).

Gnaw marks were the most encountered bite features on the cave bear limb bones from Urşilor Cave. The percentage of occurrence varied between $52.23 \%$ (for the radii) and $62.92 \%$ (for the tibiae). Intermediate values were recorded for the femora (54.6\%), ulnae (57.04 \%) and humeri (59.29\%).

Puncture marks had the highest frequency for the radii $(30.30 \%)$ and the lowest for the tibiae (16.38\%). Intermediate values were calculated for the humeri (26.55\%), femora (26.85\%) and ulnae (27.41\%). 
Tab. 1: The cave bear limb bones affected by the carnivore impact, found in Urşilor Cave. NISP = Number of Identified Specimens.

\begin{tabular}{llllll}
\hline Method & Humeri & Ulnae & Radii & Femora & Tibiae \\
\hline NISP left & 187 & 123 & 138 & 156 & 126 \\
NISP right & 146 & 121 & 117 & 181 & 129 \\
Bite marks & 113 & 135 & 99 & 108 & 116 \\
Total bitten areas & 125 & 131 & 109 & 101 & 122 \\
\% Carnivore impact left & 24.06 & 43.09 & 28.26 & 25.00 & 34.92 \\
\% Carnivore impact right & 25.34 & 35.54 & 38.46 & 25.97 & 31.78 \\
\% Gnaw & 59.29 & 57.04 & 52.53 & 54.63 & 62.93 \\
\% Puncture & 26.55 & 27.41 & 30.30 & 26.85 & 16.38 \\
\% Destruction & 14.16 & 15.56 & 17.17 & 18.52 & 20.69 \\
\% Bite marks - diaphysis & 47.20 & 49.62 & 56.88 & 58.42 & 52.46 \\
\% Bite marks - proximal epiphysis & 18.40 & 29.01 & 17.43 & 24.75 & 22.95 \\
\% Bite marks - distal epiphysis & 34.40 & 21.37 & 25.69 & 16.83 & 24.59 \\
\hline
\end{tabular}

The observed destruction marks varied between $14.16 \%$ (the humeri) and $20.69 \%$ (the tibiae). Intermediate frequencies were calculated for the ulnae $(15.56 \%)$, radii $(17.17 \%)$ and femora (18.52\%).

Among the three parts of the studied bones, the diaphysis was more frequently affected by carnivores than the epiphyses, most probably because it provides a quicker access to marrow (for durofagous predators). The percentages of damaged diaphysis varied between $47.20 \%$ (for the humeri; diaphysis relative to all carnivore impact modifications on humeri), and $58.42 \%$ (for the femora). Damage of the proximal epiphysis was between $18.40 \%$ (for the humeri; epiphysis relative to all carnivore impact modifications on humeri) and $29.01 \%$ (for the ulnae). The tooth mark values on distal epiphyis were the lowest on the femora (16.83\%), while the highest on the humeri (34.40\%).

According to Haynes (1983), identification and quantification of tooth marks may allow a more precise identification of the responsible carnivore taxon, if the bones are not being consumed exclusively. Both perpendicular diameters (i.e., length and width in $\mathrm{mm}$ ) for 69 measurable punctures identified on the cave bear limb bones varied in size and shape (Tab. 2). The humeri had punctures that ranged between $4.5 \times 6.34 \mathrm{~mm}$ and $10.65 \times 10.14 \mathrm{~mm}$ in size, the ulnae between $5.44 \times 4.57 \mathrm{~mm}$ and $7.93 \times 10.59 \mathrm{~mm}$, the radii between $4.84 \times 4.51 \mathrm{~mm}$ and $12.15 \times 9.78 \mathrm{~mm}$, the femora between $4.18 \times 3.81 \mathrm{~mm}$ and $11.43 \times 7.87 \mathrm{~mm}$ and the tibiae between $3.92 \times 4.27 \mathrm{~mm}$ and $11.11 \times 8.83 \mathrm{~mm}$.



Fig. 3: The carnivore impact on the cave bear forelimb bones found in Urşilor Cave. 


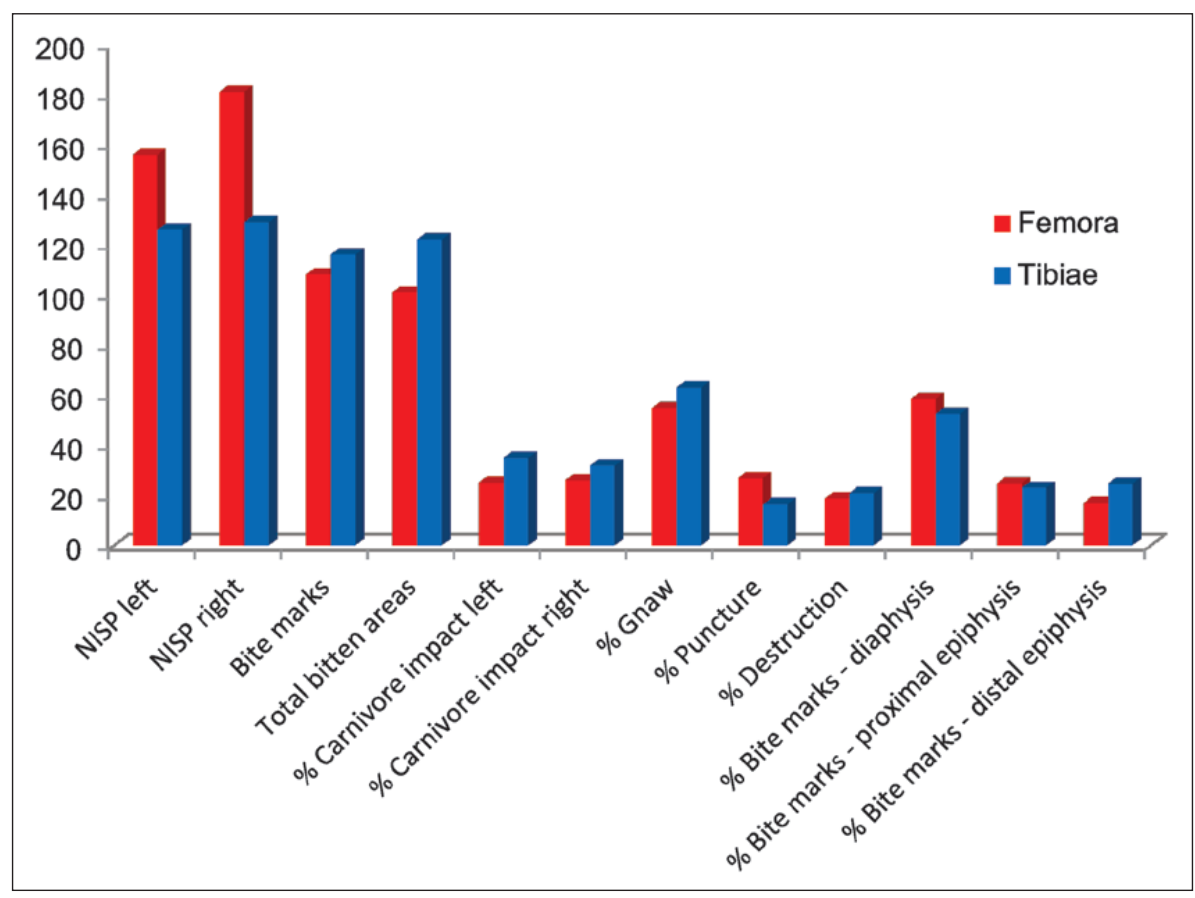

Fig. 4: The carnivore impact on the cave bear hindlimb bones found in Urşilor Cave.

The smallest and the largest measured tooth marks were found on the femur and radius, respectively (Tab. 2).

Fig. 5 shows two bivariate graphs (for cancellous and cortical bones separately) of measured punctures. The analysis was carried out in order to identify the species responsible for the bone modifications. The presence of these tooth marks indicated, that large carnivores had access to the bones.

The available comparative datasets of modern bears and modern/fossil hyenas based on punctures situated on cancellous (Fig. 5A) and cortical tissues (Fig. 5B) overlapped partially with the data obtained from Urşilor

Tab. 2: Descriptive statistics for the pits and puncture marks on the thin cortical and cancellous tissues of the cave bear long limb bones from Urşilor Cave. N: number of cases, SD: standard deviation.

\begin{tabular}{|c|c|c|c|c|c|c|}
\hline Bone/Tissue & Puncture & $N$ & Mean $(\mathrm{mm})$ & Minimum (mm) & Maximum (mm) & $S D(\mathrm{~mm})$ \\
\hline \multicolumn{7}{|l|}{ Humerus } \\
\hline Cancellous & Length & 11 & 7.44 & 4.50 & 10.65 & 1.90 \\
\hline Cancellous & Width & 11 & 6.34 & 4.11 & 10.14 & 1.80 \\
\hline \multicolumn{7}{|l|}{ Ulna } \\
\hline Cancellous & Length & 5 & 7.05 & 5.54 & 8.13 & 1.07 \\
\hline Cancellous & Width & 5 & 7.88 & 4.57 & 10.59 & 2.47 \\
\hline \multicolumn{7}{|l|}{ Radius } \\
\hline Thin cortical & Length & 3 & 7.05 & 6.25 & 7.54 & 0.70 \\
\hline Cancellous & Length & 13 & 7.23 & 4.84 & 12.15 & 1.96 \\
\hline Thin cortical & Width & 3 & 5.78 & 3.83 & 7.62 & 1.89 \\
\hline Cancellous & Width & 13 & 6.94 & 4.51 & 9.78 & 1.59 \\
\hline \multicolumn{7}{|l|}{ Femur } \\
\hline Thin cortical & Length & 4 & 5.07 & 3.11 & 7.66 & 1.95 \\
\hline Cancellous & Length & 20 & 6.49 & 4.31 & 11.43 & 1.87 \\
\hline Thin cortical & Width & 4 & 4.95 & 3.81 & 5.44 & 0.77 \\
\hline Cancellous & Width & 20 & 5.28 & 3.31 & 8.39 & 1.35 \\
\hline \multicolumn{7}{|l|}{ Tibia } \\
\hline Cancellous & Length & 13 & 6.58 & 3.92 & 11.11 & 2.18 \\
\hline Cancellous & Width & 13 & 5.64 & 3.85 & 9.56 & 2.08 \\
\hline
\end{tabular}




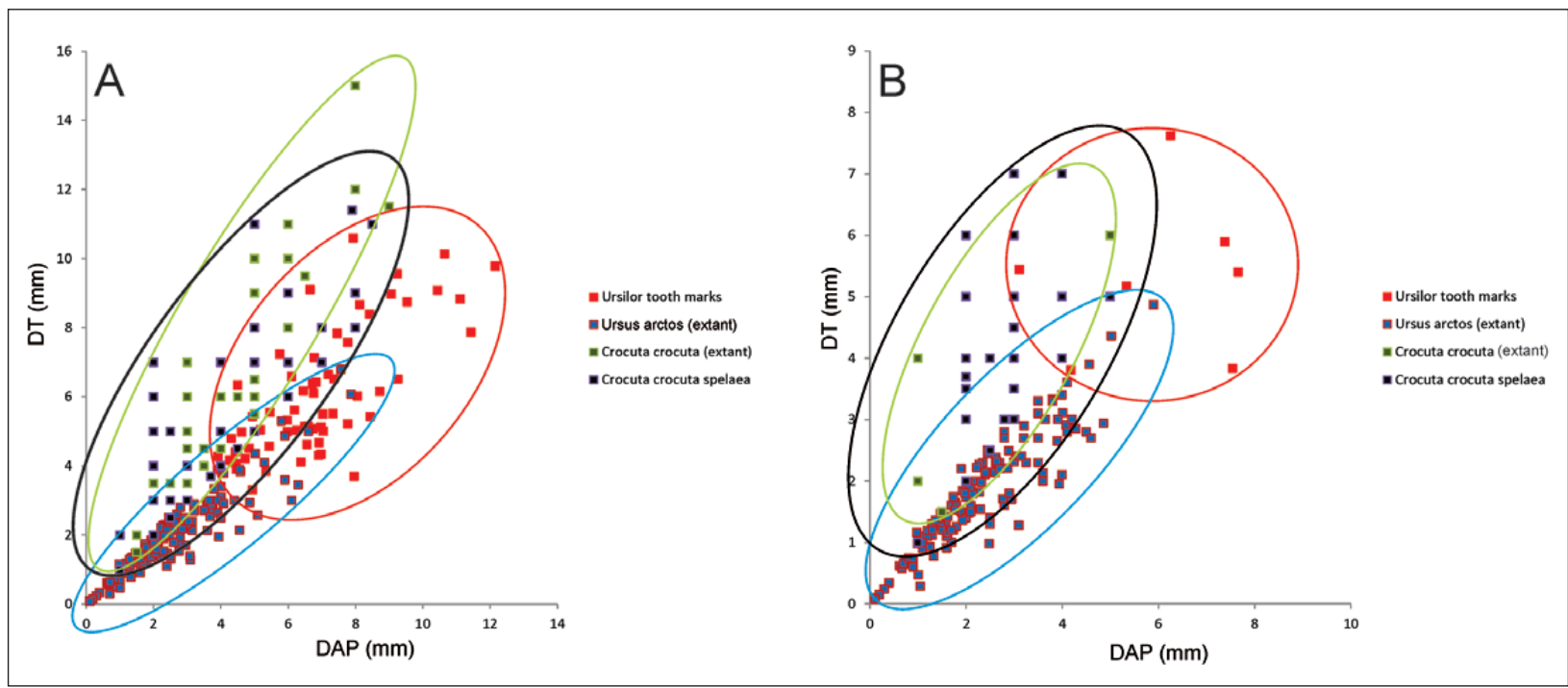

Fig. 5: Perpendicular diameters $(D A P=$ antero-posterior, $D T=$ transversal $)$ of measurable puncture marks made by modern brown bear (Ursus arctos) and modern and fossil hyenas (Crocuta crocuta and C. c. spelaea, respectively) plotted against the puncture marks found on the cave bear limb bones from Urșilor Cave. A - cancellous bone: Ursus arctos $(N=136)$, Crocuta crocuta $(N=188)$, C. c. spealea $(N=86)$, Urşilor Cave $(N=62)$. B - thin cortical bone: Ursus arctos $(N=134)$, Crocuta crocuta $(N=41), C . c . s p e a l e a(N=$ 104), Urşilor Cave ( $=7)$. Source: Arilla et al. (2014), Fourvel (2012) and the present study.

Cave. These data indicated a higher similarity between Urşilor tooth marks and the ones made by hyenas as compared to the marks made by brown bears. The lack of comparative data (e.g. felids, canids) didn't allow us to identify precisely all the responsible taxa for producing the bone modifications on the cave bear bones from Urşilor Cave. Nevertheless, the wide range of variation in size of the puncture marks indicated that: i) the species that scavenged the cave bear carcasses were of different/ various body sizes, ii) the dental morphology of the taxa creating these modifications was not uniform, iii) bone modification varied across the skeleton and differed depending on tissue type (i.e., cortical vs. cancellous bone). Therefore, most probably there were at least two scavenger species involved in the modification of the cave bear remains at Urșilor Cave.

Experimental work by Domínguez-Rodrigo et al. (2012) examined carnivore damage to five kill sites, and employed a multivariate taphonomic approach (i.e., combining furrowing and long bone end modification patterns with intensity of tooth-marking and proportion of different tooth mark types), to distinguish between the modification generated by hyenas, lions or wolves. Additionally, recent studies from the karst settlements (= cave sites) showed that Upper Pleistocene cave bears may have represented prey for other large carnivores such as large felids, hyenids and canids (e.g., Fourvel et al. 2014).

Our measurements performed on the puncture marks observed at Urşilor Cave (Fig. 5), have a cloudlike shape. The correlation between the two measured perpendicular diameters is weak $\left(R^{2}=0.49\right)$, suggesting that the increase of the antero-posterior diameter (DAP) does not correspond to the enhancement of the transversal diameter (DT) of the tooth cusps and vice versa. In other words, the low correlation between the two diameters and the wide range of the obtained values may suggest intra- and/or interspecific variation in the scavenger species at Urșilor Cave.

The morphological observations on the cave bear limb bones from Urşilor Cave, presented here, revealed that the majority of the puncture marks have a rounded to ellipsoidal shape, and the tooth impression shape in the trabecular bone is most similar to a cone or a truncated cone. Most probably, the analyzed punctures were made mainly by the cusps of the scavenger cheek teeth. According to the key of species responsible for bone destruction provided by Haynes (1983) and DomínguezRodrigo and Piqueras (2003), the data from Urşilor Cave would suggest that the cave bear bone assemblage was most likely modified by a combination of hyena, wolf and lion activity. However, we cannot exclude the possibility that the high variability recorded in the tooth marks derives from a single species (e.g., size variation related to age classes) as was recently shown for extinct and extant hyenas (Fourvel et al. 2014).

Based on analyses of grizzly bears from Yellowstone National Park, Mattson et al. (1992) concluded that cannibalism among extant bears should not be discarded since their taphonomic observations and the analysis of feces have indicated that several bears had been preyed 
Tab. 3: Index of Skeletal Disjunction (ISD) for the cave bear bone assemblage from Urşilor Cave. MDi: average minimum distance, N: number of elements.

\begin{tabular}{|c|c|c|c|c|c|c|}
\hline Bone & Nof pairs & Total $N$ & $\%$ Pairs & $M D i(m)$ & $\left(M D_{i} / \%\right.$ Pairs $) \times 100$ & $I S D$ \\
\hline Mandibles & 32 & 90 & 71.11 & 0.27 & 0.37 & 46.83 \\
\hline Humeri & 34 & 160 & 42.5 & 0.24 & 0.56 & 70.88 \\
\hline Ulnae & 20 & 53 & 75.47 & 0.37 & 0.49 & 62.02 \\
\hline Radii & 27 & 94 & 57.44 & 0.34 & 0.59 & 74.68 \\
\hline Femora & 23 & 87 & 52.87 & 0.42 & 0.79 & 100 \\
\hline Tibiae & 28 & 57 & 98.24 & 0.26 & 0.26 & 32.91 \\
\hline
\end{tabular}

upon by conspecifics. The data from Urşilor Cave therefore could also represent one of the earliest indicators that also Holocene brown bears and Upper Pleistocene cave bears might exhibited cannibalistic behavior similar to grizzly bears (e.g., Lolliot \& Philippe 2004; Crégut \& Fosse 2001; Pinto-Llona \& Andrews 2004; Rabal-Garcès \& Cuenca-Bescós 2009; Rabal-Garcès et al. 2012). However, since many other fossil carnivores were found in Urşilor Cave bone assemblage that could have generated the high variability of the tooth marks recorded here, we can't speculate upon the cave bear cannibalism.

\section{INDEX OF SKELETAL DISJUNCTION - ISD}

Among the analyzed cave bear bones, the humeri $(\mathrm{N}=160)$ were the most numerous and tibiae $(\mathrm{N}=58)$ the least numerous LLB (Tab. 3). Nonetheless, while the vast majority of the tibiae was refitted $\left(\mathrm{N}_{\text {pairs }}=28 ; \sim 98 \%\right)$, the opposite was true for the humeri $\left(\mathrm{N}_{\text {pairs }}=34 ; \sim 42 \%\right)$. The highest average minimum distance between paired skeletal elements was measured for the femora $\left(\mathrm{MD}_{\text {femora }}=0.42 \mathrm{~m}\right)$, therefore the standardized ISD was calculated based on this skeletal element. The lowest ISD were recorded for the tibiae (ISD = 32.91) and mandibles (ISD = 47). In- termediate values were obtained for the ulnae, humeri and radii. Low ISD obtained for the tibiae indicated their smallest scatter throughout the site, while higher ISD calculated for the femora indicated the opposite.

Fig. 6 indicates that the small distances recorded for the paired cave bear mandibles and limb bones were moderately correlated with the ISD values $\left(R^{2}=0.5\right)$. When analyzing both the average minimum distance $\left(\mathrm{MD}_{\mathrm{i}}\right)$ and the ISD values between the paired elements, the femora were the most scattered skeletal elements, compared to the mandibles and the other limb bones (Fig. 7).

Todd's (1987) results obtained for the ISD at the open air site of Horner II revealed a different situation from the one recorded at Urşilor Cave. However, the comparison between the two sites is inappropriate, since the analyzed species: Ursus spelaeus (Urşilor) vs. Bison antiquus (Horner Site), as well as the genesis of both bone assemblages: an Upper Pleistocene cave trap (Urşilor Cave) vs. an Early Holocene kill-butchery site (Horner), are different.

In Urşilor Cave, the general structure of displacement of the anatomically refit elements (the forelimb



Fig. 6: Relation of index of skeletal disjunction (ISD) and average minimum distance $\left(M D_{i}\right)$ for the cave bear mandibles and long limb bones from Urșilor Cave. Ma: mandibles, Hu: humeri, Ra: radii, Ul: ulnae, Fe: femora, Ti: tibiae. 


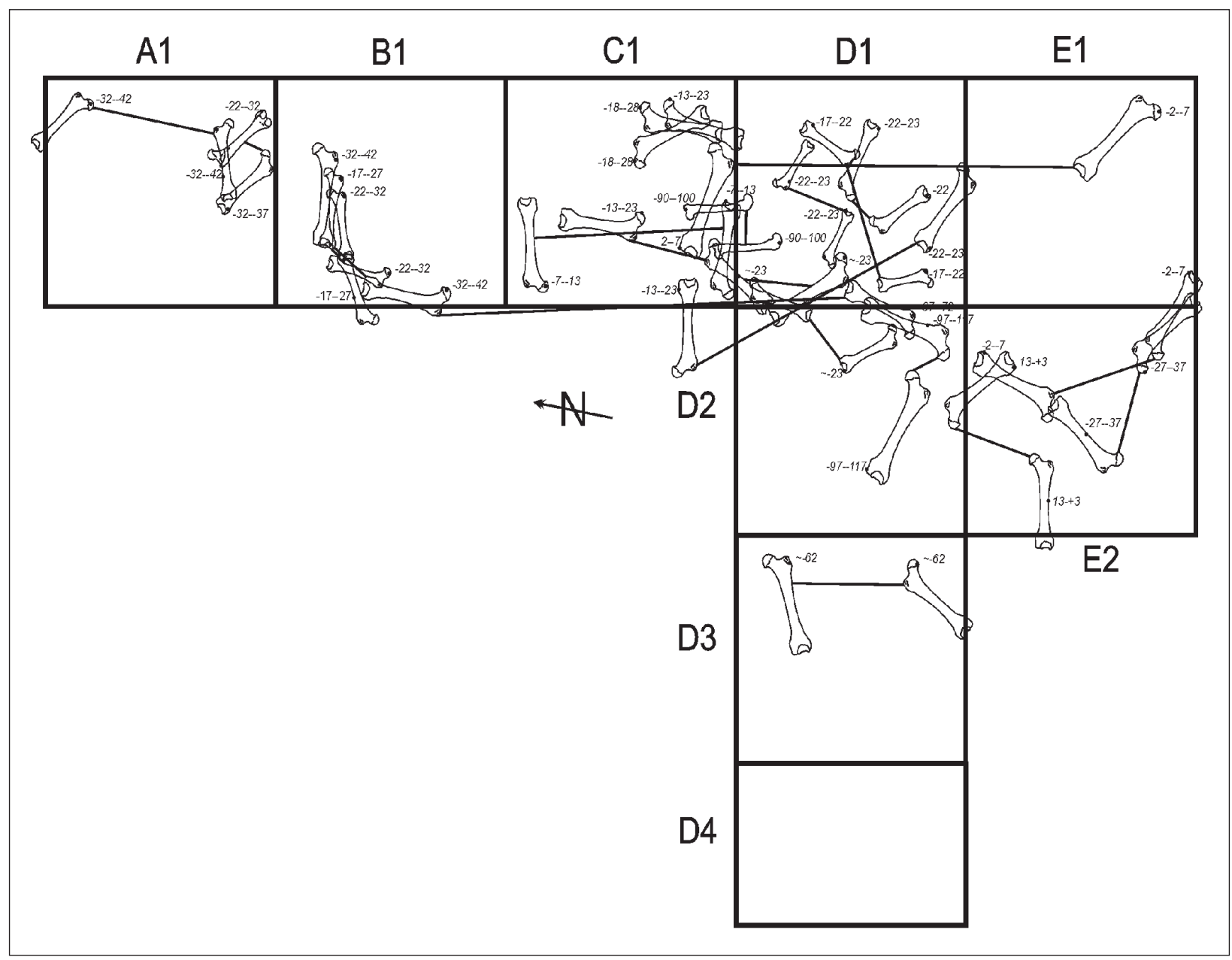

Fig. 7: Distribution of anatomically paired cave bear femora from Urșilor Cave. Note: Except the D4, all quadrants are $1 \mathrm{~m}^{2}$.

bones with high to moderate movement, while the hindlimb bones exhibit an opposite pattern) does not correspond to the model presented by Todd (1987). Nonetheless, the same ISD value was recorded for the femora from both sites (ISD $=100$ ), and similar values were recorded also for the mandibles and tibiae. The recorded femora displacement similarities between the Horner Site and Urşilor Cave may indicate a preference of the Urşilor scavengers for gnawing on the upper parts of the hind and forelimb bones (i.e., the humerus and femur). Emerson (1990) suggested that the femora display the highest ISD values because of their high meat yield, as the other skeletal parts are neither as scattered (lower ISD) nor as meaty (lower meat yield). The scattering of the complete, non-fractured bones may result from dismemberment, which enhances the transport of the skeletal parts and the removal of meat from the bones (Lyman 2004). As the carnivore impact on the Urşilor thanatocoenosis has been assessed, at least two taxa potentially responsible for the bone damage have been found and no reworking processes were recorded in the studied part of the cave (Constantin et al. 2014; Robu 2016a, b, c) it seems plausible that the recorded displacement of the cave bear bones can be associated with scavengers (carnivore impact on bones, trampling). 


\section{CONCLUSIONS}

The excavated bone deposit from Urşilor Cave (NW Romania) was analyzed. More than $30 \%$ of the cave bear limb bones (LLB) showed traces of carnivore modification - gnaw, puncture and destruction marks. Among the studied bones, the ulnae were most affected. The high variation in size and shape of the analyzed puncture marks indicated that most likely there were at least two scavenger species involved in the modification, probably the hyenas, wolves and/or lions.
Index of Skeletal Disjunction (ISD) that was calculated for assessing the degree of the cave bear mandible and limb bone scattering suggested: i) a low overall degree of bone scattering, ii) carnivore impact on bone displacement limited on in situ consumption, and iii) femora as most prone to displacement by scavengers compared to other skeletal elements (e.g., mandibles, tibiae), probably due to the highest meat yield.

\section{ACKNOWLEDGEMENTS}

The authors are indebted to Dr. Oana-Teodora Moldovan for her scientific support, to Dr. Chris Robinson, Dr. Cristian-Mihai Munteanu, Dr. Ioana-Nicoleta Meleg, Dr. Simona Prevorčnik and Dr. Claire Terhune for advices and English revision. Dr. Ruth Blasco provided data from the Pyrenees and Dr. Jean-Baptiste Fourvel from Djibouti and France. We are grateful to the volunteers from the Faculty of Geography from the Bucharest University Roxana Constantin, Alina Diaconu, Beatrice Barbu, Irina
Năstase, Alexandra Hristea, Cristian Țepurică and Teodora Badea - for helping with bone preservation, labeling and taphonomic analyses. This study was supported by KARSTHIVES Project - "Climate archives in karst", funded by CNCS-UEFISCDI Grant PCCE_ID 31/2010 (granted to Dr. S. Constantin) and is part of M.R.' PhD thesis. Two anonymous reviewers made valuable suggestions that improved significantly our manuscript.

\section{REFERENCES}

Arilla, M., Rosell, J., Blasco, R., Domínguez-Rodrigo, M. \& T.R. Pickering, 2014: The "bear" essentials: actualistic research on Ursus arctos arctos in the Spanish Pyrenees and its implications for Paleontology and Archaeology.- Plos One 9(7), e102457. http:// dx.doi.org/10.1371/journal.pone.0102457

Binford, L.R., 1981: Behavioral Archaeology and the "Pompeii Premise".- Journal of Anthropological Research, 37, 3, 195-208.

Bona, F., 2003: Associazioni faunistiche a macromammiferi della Caverna Generosa (Lo Co 2694).- Geologia Insubria, 6, 2, 1-4.

Campmas, E. \& C. Beauval, 2008: Osseous carnivores consumption: Results of the study of the carcasses of cattle (Bos taurus) exploitation by captive wolves.- Annales de Paléontologie 94, 167-186. doi:10.1016/j.annpal.2008.06.001
Constantin, S., Robu, M., Munteanu, C.M., Petculescu, A., Vlaicu, M., Mirea, I.C, Kenesz, M., Drăguşin, V., Hoffman, D., Anechitei, V., Timar-Gabor, A., Roban, R. \& C.G. Panaiotu, 2014: Reconstructing the evolution of cave systems as a key to understanding the taphonomy of fossil accumulations: The case of Urşilor Cave (Western Carpathians, Romania).- Quaternary International, 339-340, 25-40. doi:10.1016/j.quaint.2013.10.012

Crégut, E. \& P. Fosse, 2001: Holocene Brown Bears (Ursus arctos L.) in natural traps: exceptional sites of Mont Ventoux (Vaucluse, France).- Cadernos Laboratorio Xeolóxico de Laxe Coruña, 26, 325-340.

Domínguez-Rodrigo, M. \& A. Piqueras, 2003: The use of tooth pits to identify carnivore taxa in toothmarked archeofaunas and their relevance to reconstruct hominid carcass processing behaviours.Journal of Archaeological Science 30, 1385-1391. doi:10.1016/S0305-4403(03)00027-X 
Domínguez-Rodrigo, M., Gidna, A.O., Yravedra, J. \& C. Musiba, 2012: A comparative Neo-Taphonomic Study of Felids, Hyaenids, and Canids: an Analogical Framework Based on Long Bone Modification Patterns.- Journal of Taphonomy, 10, 3-4, 151-170.

Döppes, D., 2004: Carnivores and marmots from the Upper Pleistocene sediments of Potocka zijalka (Slovenia).- In: Pacher, M. et al. (eds.) Potočka zijalka. Palaeontological and archaeological results of the campaigns 1997-2000. Mitteilungen der Kommission für Quartärforschung der Österreichischen Akademie der Wissenschaften, 13, pp. 67-80, Wien.

Emerson, A.M., 1990: Archaeological implications of variability in the economic anatomy of Bison bison.- $\mathrm{PhD}$ thesis, Washington State University, pp. 1792.

Fosse, P., Besson, J.P., Laborde, H., Thomas-Cantie, F., Cazenave, G., Delmasure, M.C., Leveque, T., Laudet, F. \& J. Quilès, 2004: Denning behaviour of "modern" brown bear (Ursus arctos, L.) in caves: biological and paleontological considerations from French Pyrenean sites.- Cahiers scientifiques, 2, $171-182$.

Fourvel, J.B., 2012: Hyénidés modernes et fossiles d'Europe et d'Afrique : taphonomie comparée de leurs assemblages osseux.- PhD thesis, Université Toulouse le Mirail - Toulouse II, pp. 597.

Fourvel, J.B., Fosse, P., Brugal, J.P., Tournepiche, J. F. \& E. Crégut-Bonnoure, 2012: Consumption of Ungulate Long Bones by Pleistocene Hyaenas: a Comparative Study.- Journal of Taphonomy, 10, 3-4, 239-263.

Fourvel, J.B., Fosse, P., Crégut-Bonnoure, E., Slimak, L. \& J.F. Tournepiche, 2014: Characterization of bear remains consumption by Pleistocene large carnivores (Felidae, Hyaenidae, Canidae).- Quaternary International, 339-340, 232-244. doi:10.1016/j. quaint.2013.08.024

Haynes, G., 1980: Evidence of carnivore gnawing on Pleistocene and Recent mammalian bones.- Paleobiology, 6, 341-351.

Haynes, G., 1983: A guide for differentiating mammalian carnivore taxa responsible for gnaw damage to herbivore long bones.- Paleobiology, 9, 2, 164-172.

Jurcsák, T., Plopiş, R., Ignat, D., Şerban, M. \& E. Popa, 1981: Date privind fauna fosilă a Peşterii Urşilor (M. Bihor).- Nymphaea, 8-9, 161-257.

Lolliot, S. \& M. Philippe, 2004: Note préliminaire sur les traces de charognage affectant les ossements d'ours des cavernes, Ursus spelaeus, de la Balme à Collomb (Entremont-le-Vieux, Savoie); en exemple: le cas des fémurs.- Cahiers scientifiques, Hors-série, 2, 115-120.
Lyman, R.L., 2004: Vertebrate Taphonomy. Cambridge University Press, pp. 524, Cambridge.

Maguire, J.M., Pemberton, D. \& M.H. Collett, 1980: The Makapansgat Limeworks Grey Breccia: hominids, hyaenas, hystricids or hillwash?.- Paleontologia Africana, 23, 75-98.

Martínez-Sánchez, R.M., López-García, J.M., AlcaláOrtíz, A., Blain, H.A., Rabal-Garcés, R., BretonesGarcía, M.D., Rodríguez-Vidal, J. \& A. MartínezAguirre, 2012: Bears and hyenas from the latest Pleistocene of Southern Iberia: Sima de Abraham, Priego de

Córdoba, Andalusia.- Journal of Taphonomy, 10, 3-4, 545-559.

Mattson, D.J., Knight, R.R. \& B.M. Blanchard, 1992: Cannibalism and Predation on Black Bears by Grizzly Bears in the Yellowstone Ecosystem, 1975-1990.Journal of Mammalogy, 73, 2, 422-425.

Pacher, M., 2000: Taphonomische Untersuchungen der Höhlenbärenfundstellen in der SchwabenreithHöhle bei Lunz am See (Niederösterreich).- Beiträge zur Paläontologie, 25, 11-85.

Pacher, M., 2004: Taphonomic analyses of cave bear remains from Potočka zijalka (Slovenia): Spatial distribution analysis.- In: Pacher, M. et al. (eds.) Potočka zijalka. Palaeontological and archaeological results of the campaigns 1997-2000. Mitteilungen der Kommission für Quartärforschung der Österreichischen Akademie der Wissenschaften, 13, pp. 123-139, Wien.

Pacher, M. \& J. Quilès, 2013: Cave bear paleontology and paleobiology at the Peștera cu Oase: Fossil population structure and size variability.- In: Trinkaus E. et al. (eds.) Life and death at Peștera cu Oase. Oxford University Press, pp. 127-147, New York.

Pinto-Llona, A.C. \& P.J. Andrews, 2004: Scavenging behaviour patterns in cave bears Ursus spelaeus.- Revue de Paléobiologie, 23, 2, 845-853.

Quilès, J., 2003: Les Ursidae du Pléistocène Moyen et Supérieur en Midi Méditerranéen: Apports paléontologiques, biochronologiques et archéozoologiques.$\mathrm{PhD}$ thesis, Museum National d'Histoire Naturelle, t. I: pp. 604, t. II: pp. 643, Paris.

Quilès, J., Petrea, C., Moldovan, O., Zilhao, J., Rodrigo, R., Rougier, H., Constantin, S., Milota, Ş., Gherase, M., Sarcină, L. \& E. Trinkhaus, 2006: Cave bears (Ursus spelaeus) from Peştera cu Oase (Banat, Romania): Paleobiology and taphonomy.- Comptes Rendus Palevol, 5, 927-934. doi:10.1016/j.crpv.2006.09.005

Rabal-Garcés, R. \& G. Cuenca-Bescós, 2009: Tafonomía del yacimiento de osos De Las Cavernas De Coro Tracito (Tella, Huesca, España).- Paleolusitana, 1, 398-399. 
Rabal-Garcés, R., Cuenca-Bescós, G., Canudo, J.I. \& T. de Torres, 2012: Was the European

cave bear an occasional scavenger?.- Lethaia, 45, 96-108. doi:10.1111/j.1502-3931.2011.00260.x

Robu, M., 2015: The palaeontology of the cave bear bone assemblage from Urşilor Cave of Chişcău - Osteometry, Palaeoichnology, Taphonomy, and Stable Isotopes.- Editura Universitară, pp. 248, Bucharest. doi:10.5682/9786062804008

Robu, M., 2016a: Fossil population structure and mortality analysis of the cave bears from Urşilor Cave, North-Western Romania.- Acta Palaeontologica Polonica, 61, 2, 469-476. doi: 10.4202/app.00201.2015

Robu, M., 2016b: The assessment of the internal architecture of an MIS 3 cave bear bone assemblage. Case study: Urşilor Cave, Western Carpathians, Romania.- Palaeogeography, Palaeoclimatology, Palaeoecology, 444,115-123. doi:10.1016/j. palaeo.2015.12.012

Robu, M., 2016c: Age re-assessment of the cave bear assemblage from Urşilor Cave, north-western Romania.- International Journal of Speleology, 45, 2, 123-133. doi:10.5038/1827-806X.45.2.1947

Shipman, P., 1981: Life History of a Fossil: an Introduction to Taphonomy and Paleoecology.- Harvard University Press, pp. 222, London.
Stiner, M.C., Aarsenbuk, G. \& F.C. Howell, 1996: Cave bears and Paleolithic artifacts in Yarimburgaz Cave, Turkey: dissecting a palimpsest.- Geoarchaeology, 11, 4, 279-327. doi: 10.1002/(SICI)1520-6548(199607)11:4<279::AID-GEA1>3.0.CO;2-Z

Terzea, E., 1978: Dèpot de remplisage et Mammiferes quaternaires de "Peştera Urşilor", de Chişcău, departament de Bihor (Note préliminaire).- Travaux de l'Institut de Spéologie "Emil Racovitză", 17, 139-144.

Terzea, E., 1989: Les Arvicolidés (Rodentia, Mammalia) du Pléistocène Moyen de Chişcău-1 (Depart. de Bihor, Roumanie).- Travaux de l'Institut de Spéologie "Emil Racovitza", 28, 57-72.

Tintori, A. \& E. Zanalda, 1992: Ursus spelaeus dal Massiccio di Campo dei Fiori (VA): tracce di predazione.- Bollettino della Società Ticinese di Scienze Naturali, 80, 1, 97-103.

Todd, L.C., 1987: Taphonomy of the Horner II bone bed.- In: Frison, G.C. \& L.C. Todd (eds.) The Horner Site: the type site of the Cody Cultural Complex. Academic Press, pp. 107-198, Orlando. 